has been developed to overcome this difficulty. A standard unit of expression of a bull's genotype is first defined. This is one progeny expression in the year in which the bull is selected. All future expressions of his genotype that follow from a single insemination over a specified number of years are then converted into standard units by a series of adjustments which allow for the dilution of the bull's genotype in his descendants, the time interval before these descendants appear, and the probability that they will express either his dairy or his beef genotype. The appropriate weight to give any trait in the breeding objective is then the product of the financial value per unit improvement in that trait and the number of standard expressions which will follow from one insemination. Once the breeding objective or aggregate genotype has been specified in this way, index selection of bulls can be arranged to maximize the economic benefit conferred on the population with each insemination.

The balance of emphasis on beef and dairy traits is most affected by the probability that a successful insemination results in a dairy replacement heifer. This probability in turn depends on the percentage of cows crossed to beef bulls and on the cow replacement rate. As the beef crossing percent and the cow turnover rate increase, the emphasis moves very much in favour of dairy traits.

The general consequences of this are :

I. It appears that the most efficient breeding programme for milk and beef in a dual purpose population will require the maximum amount of crossing with beef breed bulls that is compatible with the provision of cow replacements.

2 If all other factors are constant, the effect of increasing the level of crossbreeding by I p. Ioo is to increase the economic value of the genetic merit conferred with each dual purpose insemination by approximately $\mathrm{I}$ p. roo.

3. A second effect of increasing the percentage of cows bred to beef bulls is to greatly increase the emphasis which should be given to milk production in the selection of dual purpose bulls.

4. The percentage of total economic gain from purpose bull seelection which is accounted for by improvement of milk yield varies from $75 \mathrm{p}$. roo to nearly roo p. Ioo. If $20 \mathrm{p}$. Ioo or more of the cows are bred to beef bulls, the percentage is always over 85 p. Ioo.

5. A high cow replacement rate has an effect similar to a high level of beef crossing, i.e., it increases the emphasis on and return via milk.

6. The effects of level of crossbreeding and cow replacement rate on both the total gain from selection, and on the balance of gain via milk and beef, comes for the most part through their effects on the number of expression of a bull's genotype for milk and beef.

7. By comparison, variation in the relative economic values of I $\mathrm{kg}$ of liveweight to $\mathrm{I} \mathrm{kg}$ of milk $(6,7,8)$ and in the genetic correlation between these traits $(-0.2,0.0,+0.2)$ had small effects.

8. A high level of beef crossing and/or a high cow replacement rate greatly enhances the return on investment in the testing and selection of dual purpose bulls.

\title{
CaractéRISTIQUeS qualitatives DE LA VIANDE CHEZ DES PORCS DE RACE PURE OU HYBRIDES
}

\section{R. FAbBri, M. Manfredini et P. Semprini *. - Institut expérimental de Zootechnie, Modène (Italie). - * Institut de Zootechnie générale, Université de Bologne (Italie).}

A la station de recherches porcines de Modène on a comparé des porcs Large White hollandais, Landrace, Piétrain ainsi que des hybrides Costwold (G.-B.) Hyper (Hollande) et T.W.B. (États-Unis).

Pour chaque race sauf le Piétrain qui n'en avait qu'un seul on disposait de deux lots de 8 porcs (mâles castrés et femelles). L'aliment dans tous les cas avait une composition optimale pour équilibrer la ration. Au cours de l'expérience, les porcs étaient menés de 33 à $9 \mathrm{I}-93 \mathrm{~kg}$.

On a mesuré l'accroissement journalier, l'indice de consommation, le rapport viande/graisse de la carcasse, la surface du muscle Longissimus dorsi. La qualité de viande a été jugée par le pourcentage de la matière sèche en protides et en lipides et la couleur.

On remarque tout d'abord un rapport très favorable viande sur graisse $(1,93)$ des $T$. W. B. qui se classent immédiatement après les Piétrains $(2,42)$, par ailleurs, la tendreté de la viande est garantie par le rapport lipide sur protide le plus élevé de la comparaison I5, 10/74, Io. 
Pour le Piétrain à la carcasse très riche en viande cette dernière garde une teneur en lipide qui garantit sa tendreté II,I9/77,90. Ainsi observe-t-on qu'une carcasse maigre peut très bien donner une viande suffisamment chargée en lipide pour rester tendre.

En outre on a observé que la teneur en lipide dépendait de l'alimentation : les lots qui ont reçu l'aliment le plus riche en maïs présentaient un pourcentage plus élevé de graisse de constitution.

Ainsi, grâce à la génétique et en surveillant l'alimentation, on peut obtenir un porc dont les qualités de viande surpassent nettement celles des races pures traditionnelles.

\section{EFFECTIVENESS OF BOAR PERFORMANCE TEST SELECTION INDEXES}

E. P. Cunningham and P. Power. - Animal Breeding and Genetics Department, An Foras Taluntais, Dublin. - Livestock Section, Dept. of Agriculture and Fisheries, Dublin (Eire).

Five possible indexes for use in selecting boars on performance test were evaluated. The selection objective in all cases was a linear economic function of the boars's genotype for daily gain, feed efficiency and carcass lean content. Eleven items of information were available for inclusion in the index. These were the recorded daily gain, feed efficiency and backfat of boar, two full sibs and nine half sibs, together with part carcass dissection data on two full and six half sibs. The indexes considered were :

r. Full index including $\mathbf{r}$ items of information.

2. Information on feed efficiency omitted.

3. Information on feed efficiency and part carcass dissection omitted.

4. All half and full-sib information omitted.

5. All half-sib information omitted.

The relatives rates of genetic change to be expetecd from using these indexes were roo, 9o, 85, 86 and 96. Within each index, boar backfat was the most useful item of information, followed by boar feed efficiency, or, where feed efficiency was not recorded, boar daily gain.

The most valuable item of sib data was the part dissection on two full sibs, though its omission never caused more than a $4 \mathrm{p}$. Ioo drop in index efficiency.

The percentage of the economic value of the genetic gain achieved attributable to change in each trait was measured. The proportions were quite similar for all indexes. About 6 p. Ioo was due to improvement in daily gain, 33 p. Ioo to improvement in feed efficiency and 6r p. Ioo to increased carcass lean content. 